\title{
PERAN LATUPATI SEBAGAI LEMBAGA HUKUM ADAT DALAM PENYELESAIAN KONFLIK ANTAR NEGERI DI KECAMATAN LEIHITU PROPINSI MALUKU
}

\author{
Oleh: J. Sahalessy
}

\begin{abstract}
Sense of security, order and peace is a basic requirement in the life of a people a very close relationship with law enforcement process. Process of law enforcement in the area of customary law community unit as in the countries of the Moluccas should be understood as a unit which can't be separated from their culture. Role of Institutions Latupati be one of the institution of customary law (adat institution) which is a cultural identity of indigenous people in Maluku in the resolution of conflicts between countries. Awareness of the legal sistem in fact is at the core of the culture of a community. For those reasons, the existence of latupati institutions need to be maintained and enhanced as an instrument of social control of society, so that the future of this institution is able to contribute to process of law, especially in sub Leihitu.
\end{abstract}

\section{Keyword: The Role of Customary Law Latupati as Institutions, Conflict Resolution and Inter-State District Leihitu}

\section{A. LATAR BELAKANG.}

Masyarakat adat merupakan elemen terbesar dalam struktur Negara Bangsa (Nation-State). Pendiri negara Indonesia sejak semula sudah menyadari baha Negara ini adalah Negara kepulauan yang majemuk baik sistem politik dan sistem hukum maupun sistem sosial budaya dan agama. Daerah kesatuan masyarakat hukum adat seperti negeri-negeri di Maluku pada umumnya, untuk mewujudkan kesejahteraan, ketertiban dan keamanan masyarakat dibutuhkan peran aktif dari seluruh elemen masyarakat untuk mampu mengembangkan potenssi yang ada termasuk lembaga-lembaga hukum adat.

Salah satu lembaga hukum adat (institui adat) di Kecamatan Leihitu ialah Latupati. Lembaga ini merupakan perserikatan raja-raja di Kecamatan Leihitu. Lembaga ini dapat ditukan pula pada negrinegri lain di Maaluku seperti Pulau haruku, Sparua dan sebagainya. Kondisi keamanan di wilayah Kecamatan Leihitu yang akhirakhir ini sering terganggu, memungkinkan semua pihak untuk turut ambil bagian dalam penyelesaiannya, karena hal ini telah menjadi tangung jawab bersama masyarakat ddan pemerintah.

Gangguan keamanan yang terjadi di wilayah ini antra lain konflik horizontal antara Negeri Mamala dengan Morela yang diawali pada aat masyarakat kedua negeri merayakan upacara adat "Pukul Sapu 6 sya'wal 1620 H" . Konflik yang terjadi pada hari kamis 24 November 2005 tersebut telah memakan korban jiwa dan harta benda, sehingga mengundang perhatian publik dengan seribu tanda tanya,mengapa hal seperti ini terjadi?. Padahal kedua negeri yang terlibat konflik tersebut masih berasal darri satu garis keturunan (genealogis) orang basudara yang konon pernah hidup bersamapsama dalam satu negeri. Dan yang sangat mengherankan adalah faktor penyebab tersebut, selain dipengaruhi oleh kenalkalan remaja juga dipengaruhi oleh panatisme adat yang berlebihan (ego cultur). Berdasarkan keterangan masyarakat setempat bahwa konflik seperti ini sering terjaddi berulang-ulang. 
Kesadaran Lembaga Latupati Kecamatan Leihitu dalam menyikapi konflik semacam ini ssangat dibutuhkan, arena telah diakui dan memiliki pengaruh yang positif bagi kesejateraan dan ketertiban pada masyarakat hukum adat di wilayah tersebut. Salah satu diantaranya adalah peran Lembaga Latupati dalam menyikapi perjanjian perdamaian antara negeri Wakal dan Negeri Hila tanggal 23 April 2002 yang tertuang dalam satu kesapakatan yang disebut kesapakatan Latupati. Kesepakatan tersebut diambil sebagai bentuk tanggung jawab moral terhadap ganguan keamanan di wilayah toritorial mereka. Konflik antara negeri Wakal dengan negeri Hila tersebut disebabkan karena masalah keenakalan remaja, minuman keras, dan politik perdagangan. Perjanjian perdamaian tersebut melibatkan raja, tokoh adat, tokoh agama, dan tokoh pemuda kedua negeri dengan cara musyawarah untuk mufakat guna mencari solusi penyelesaian konflik tersebut yang biasanya diakhiri dengan sumpah adat sebagai tanda perdamaian. Penjelasa ini menggambarkan bahwa keberadaan latupatti sebagi Lembaga Hukum Adat memiliki pengaruh tersendiri terhadap penyelesaian konflik pada negerinegeri adt di Kecamatan Leihitu dan Maluku pada umumnya.

Berdasarkan urian latar belakang masalah di atas, maka yang menjadi rumusan masalah dalam penelitian ini adalah sebagai berikut : Bagaimana peran dan Lembaga Latupati dalam penyelesaian konflik antara negeri adat di Kecamatan Leihitu?

\section{B. PEMBAHASAN}

\section{Konflik Antar Negeri Adat di Kecamatan Leihitu}

Salah satu masalah hukum dan proses peenegakkannya pada daerah-daerah kesatuan masyarakat hukum adat di Kecamatan Leihitu adalah yang timbul dalam konteks konflik horizontal antara negeri adat, seperti yang terjadi pada beberapa kurun waktu terkahir. Apa yang disebut sebagai konflik antar negeri adat merupakan sebuah realitas pada masyarakat yang memiliki latar belakang budaya tertentu. Konflik semacam ini pun dinilai sebagai nampak kemanusiaan yang terjadi di maaluku selama kurang lebih empat tahun, yang berpengaruh terhadap sistem kesatuan hidup masyarakat adt di Jazirah Leihitu dengn terputusnya satu tali generasi (one lost generation).

Aspek yang paling banyak mendapat sorotan adalah proses penegakan yang sampai saat ini belum memperlihatkan hasil yang memuaskan. Masyarakat sering mempertanyakan kinerja aparatur penegak hukum, sehingga hukum belum bisa mengambil peran optimal untuk kepentingan ketentraman masyarakat. Untuk itulah perlu dicari yang dapat memberikan arah bagi terwujudnya kondisi aman dan tentram bagi masyarkat hukum adat khususnya di Kecamatan Leihitu. Sebagai upaya membantu pemerintaah dalam proses penegakkan hukum di Maluku.

Untuk terwujudnya kondisi tersebut, penulis berpendapat bahwa keberadaan institusi adat (Latupati) di Kecamatan Leihitu perlu dijadikan sebagai sarana utama, bekerja sama dengan pemerintah untuk menciptakan perdamaian antara negeri adat di Kecamatan Leihitu akibat konflik horizontal.

Beberapa contoh kasus tentang koflik antar negeri adat dan peran latupati dalam penyelesaiannya yang pernah terjadi di kecamatan Leihitu diantaranya :

1. Konflik antar negeri Asilulu dengan Negeri Ureng

Konflik antar dua negeri ini pernah terjadi pada tahun 2001. Konflik ini terjadi pada saat semua masyarakat di Kecamatan Leihitu sedang berekreasi di daerah wisata Pulau Tiga (Asilulu) bertepatan dengan perayaan hari keetiga Lebaran Idul Fitri 1420 H. Kejadian tersebut berawal ketika speed boat milik 
warga Ureng yang dikendarai dalam keadaan mabuk menabrak seorang anak warga Asilulu yang sedang bermain di tepi pantai Pulau Tiga. Akibat dari peristiwa itu warga ureng tersebut dihakimi oleh warga asilulu yang saat itu brada di tempaat kejadiaan. Mderasa tidak puas dengan aksi masa yang dilakukan oleh warga asilulu yang mengakibatkan korban meninggaal dunia, aka pada malam hari warga Ureng melakukan serangn balasan kepada warga Asilulu dengan membakar pemukiman penduduk. Peritiwa itu menyebabkan jatuhnya korban jiwa dan harta benda dari kedua negeri yang bertikai.

Lembaga Latuputi telah berupaya untuk mendamaikan konflik, walaupun pada pelaksanannya banyak kendala yang dihadapi oleh lembaga ini, karena salah satu negeri yang bertiki bersikers untuk menyelesaikan konflik melalui jalur pengadilan dengan membentuk satu tim pengacara yang mengatasnamakan negeri tanpa menghiraukan proses perdamaian yag ditawarkan oleh lembaga latupati. Namun dengan semanagat dan perjuangan keras lembaga ini pula maka proses peerdamaian antara kedua negeri tetap berjalan bersamaan dengan proses hukum tersebut.

2. Konflik antar negeri Hitu Lama dengan negeri Hitu Messeng

Konflik antar kedua negeri ini pernah terjadi pada tahun 2005, berdasarkan keterangan yang diperoleh bahwa konflik ini pernah terjadi pada tahun sebelumya dan bisa saja terjadi pada masa-masa yang akan dating dengan alasan kenalakan remaja dan perkembangan zaman. Lembaga latuputi telah melibatkan diri secara proaktif, bermusyawarah dengan para tokoh dari kedua negeri untuk mencari jalan keluar sebagai upaya penyelesaian konflik serta meningkatkan keamanan antar kedua negeri untuk mencari jalan keluar sebagai upaya penyelesaian konnflik sertaa meningkatkan keamanan antar kedua negeri. Konfik ini akan sulit diselesaikan apabila masing-masing memmpertahankan egoisme mereka dn tidak pernah mau duduk bersama dalam satu meja untuk saling membuka diri, mengakui kekurangan pada masingmasing negeri sebagai bentuk itikad baik kedua negeri untuk bersatu kembali dalam konsep-konsep pemikiran tentang sejarah dan truktur adat mereka.

Menyikapi konflik tersebut, lembaga latupati bersama dengn tokoh pemuda leihitu menyatakaan sikap dalam rapat tanggal 10 April 2002 yang isinya mengutuk sekeras-kerasnya perbuatan tersebut serta menuntut agar sesegera mungkin menyerahkan para pelaku pembantaian kepada pihak yang berwewenang dalam $1 \mathrm{x}$ 24 jam. Dalam usaha menciptkana perdamaian yang hakiki antara kedua negeri, latupati beserta tokoh agama, tokoh masyarakat, tokoh pemuda dan para tokoh adat kedua neeri yang bertiki menyepakati satu perjanjian perdamaian tanggal 23 Apil 2002. Untuk mewujudkan hassil kesepakatan tersebut, maka dilakukan upacara sumpah adat sebagai bentuk perdamaian.

\section{Faktor-Faktor Yang Mempengaruhi Konflik}

Berdasarkan hasil penelitian secara empiris yang dilakukan oleh peneliti terhadap peran lembaga latupati dan fenomena sosial yang terjadi pada kesatuan masyarakat hukum adat Jazirah Leihitu dalam konteks konflik antar negeri adat, maka faktor-faktor yang berpengaruh terhadap timbulnya konflik dapat didefenisikan sebagai berikut :

a. Minuman Keras (Miras)

Dari sekian konflik yang terjadi pada negeri-negeri adat di Kecamatan Leihitu lebih banyak di picu oleh minuman keras. Hal ini dibuktikan dengan tingginya angka kriminalitas menurut data dari pihak kepolisian 
(Polsek Leihitu). Hal ini disukung dengan semakin maraknya perdagangan minuman keras di Kecamatan Leihitu. Dapat dibayangkan berapa jumlah pecandu Miras oleh masyarakat Leihitu apabila oleh masyarakat Leihitu apabila pada setiap negeri terdapat kurang lebih lima Bandar Miras. Jumlah pecandu ini akan terus meningkat dan lebih banyak terlihat pada acara hiburan tertentu yang sangat berpeluang terhadap suatu tindak krriminal baik antara sesama pecandu atau dengan masyarakat lain ampai pada meletusnya konflik antar negeri. Globalisasi menyebabkan masyarakat menjadi sekuler akibat perjumpaan sehingga terjadinya benturan-benturan nilai dalam lingkungan masyarakat kita. Adat sebagai norma dan aturn yang turut membantu membentuk perilaku seseorang dalam masyarakat menjadi ikut terkikis.

b. Kenakalan Remaja (Generasi Muda)

Kenakalan remaja telah menjadi isu lokal yang mempengaruhi tingkat kamanan di Kecamatan Leihitu. Akibat dari kenakalan remaja ini biasanya akan menjalar sampai tauran antar negeri. Ada suatu konsekuensi dari salidaritas yang kuat antara para remja dan masingmasing negeri, ini adalah suatu fenomena buruk yang sangat disesalkan. Dalam menyikapi setiap persoalan antara individu mereka tidak memikirkan latar belakang dan dampaknya terhadap masyarakat secara keseluruhan, sehingga akan melibatkan kelompok masyarakat yang lebih luas.

Tingkah laku seseorang (melanggar kaidah) ditentukan oleh sikapnya (attitude) dalam menghadapi suatu situasi tertentu. Sikap ini ditentukan oleh kesadaran subjektif akan nilai dan norma dari masyarakat atau kelompoknya. Nilai dan kelompok ini dihayati oleh indivdu dari dan dalam kebudayaan di mana dia dilahirkan dan di besarkan, seorang individu yang melanggar norma mempunyai sikap tertentu terhadap situasi yang diatur dalam norma yang bersangkutan. Sikap ini adalah hasil dari sosialisasi individu.

c. Fanatime Adat (ego kultur)

Selain minuman keras dan kenakalan remaja ada pula suatu hal penting yang sangat berpengaruh terhadap timbulnya konflik antar negeri adat di Kecamatan Leihitu yaitu masalah fanatisme adat (ego kultur). Hal semacam ini sering dijadikan sebagai isu utama pemicu konflik yang berpengaruh terhadap terkikisnya budaya orang basudara di Maluku.

Konflik antar negeri sebagai akibat dari fanatisme adat harus dipelajari secara khusus agar kedepan tidak timbul konflik serupa dengan alasan yang sama. Charles Taylor mengatakan bahwa masing-masing agama dan budaya menuntut pengakuan dan penghargaan semua orang.

\section{Proses Penyelesaian dan Sanski}

Sebagai salah satu hukum adat, dalam menjalankan perannya untuk menyelesaikan konflik antar negeri di Kecamatan Leihitu. Lembaga Latupati selalu berupaya untuk menuju kepada perdamaian yang hakiki dengan semangat kearifan dan moral yang tinggi sesuai nilainilai (karakteristik), dasar perekat (idiologi) serta pemersatu (integritas) yang menunjukan lembaga ini sebagai identitas kebudayaan local masyarakat Leihiitu (local culture identity)

Penulis berpendapat apa yang dilakukan oleh lembaga Latupati dalam penyelesaian konflik horizontal ini harus dijadikan sebagai saran-saran konstruktif kepada pemerintah daerah, aparat penegak hukum dan pradigmaa baru negeri-negeri di Maluku pada umumnya sebagai upaya confilt resolution.

Untuk menjalankan tugas moral tersebut, lembaga Latupati menyusun beberapa langka sebagai pola penanganan 
yang terbagi kedalam empat tahap pertemuan menuju kepada perdamaian, yaitu sebagai berikut :

1. Latupati dengan Para Raja (Pemimpin Negeri).

Ini merupakan proses awal dari suatu perdamaian antar negeri adat di kecamatan Leeihitu, sebagai bentuk kerja sama dari orang-orang yang mempunyai kepentingan dan tujuan-tujuan yang sesuai menuju kea rah perundingan

2. Latupati dengan Staf Negeri (Saniri).

Adapun yang dilakukan oleh lembaga Latupati pada tahap ini bertujuan mengidentifikasi itikad baik (hati nurani) dari du negeri untuk berdamai. Pertemuan ini dilakukan secara sepihak antara lembaga latupati dengan saniri negeri dengan cara mendatangi suatu negeri terlebih dahulu dan dilanjutkan ke negeri berikutnya. Dalam proses ini terjadi tawarr menawar antara lembaga latupati dengan saniri dari negeri yang bertikai mengenai jalan keluar menghentikan konflik yang terjadi. Apabila telah dihasilkan kata sepakat maka hasil musyawarah ini ditawarkan kepada masyarakat untuk ditindaklanjuti secara bersama-sama atas dasar mufakat olidaritas dan itikad baik.

3. Latupati dengan Para Tokoh (Adat, Masyarakat, Agama dan Pemuda darri Negeri tang bertikai).

Ini merupakan tahap lanjutan dari pertemuan kedua yang dilakukan oleh lembaga latupati. Tahap ini menggambarkan eksepsi (penerimaan) pihak ketiga oleh negeri yang bertikai, latupati dan keberadaannya dipandang sebagai suatu lembaga yang independen. Inilah kondisi pembatas yang penting jika salah satu pihak misalnya mengidentifikasikan untuk menrapkan pendekatan proses menjadi sangat kecil

4. Latupati dengan Seluruh Masyarakat (Saniri Besar) Negeri yang bertikai.

Tidak semua penyelesaian konflik antar negeri adat di Kecamatan Leihitu diakhiri dengan sumpah adat. Sumpah adat biasanya dilakukan sebagai wujud nyata dari suatu perdamaian antar negeri. Upcara adat ini dilakukan agar perdamaian ini dapat ebih mengikat secara moral bagi asyarakat Leihitu pada umumnya. Untuk itu peelaksanaan sumpah adat memiliki nilai tersendiri dalam mepertahankan dan mengawal perdamaian tersebut. Sesuai dengan kekuatan spiritual dan kultural yang dipercayai mempengaruhi pergaulan hidup antar masyarakat adat di Jazirah Lihitu dan sebagai penjaga eksistensi identitas asli orang Maluku. Kekuatan mengikat perjanjian didasarkan pada asas yang tertuang dalam Kapata "Yale Hale Hatu, Hatu Hale Sei " yang artinya barang siapa membalik batu (adat), batu atau adat tersebut blik menindis dia. Asas seperti ini dikenal dalam hukum internasional dengan asas " Pacta sunt servanda “

Sanksi yang diberikan terhadap negeri yang tidak mentaati keputusan kesepakatan suatu perjanjian perdamaian lembga latupati dapat berupa sanksi adat dan sanksi sesuai hukum negara.

Terdapat beberapa jenis dan bentuk sanksi yang menjiwai hukum adat di Kecamatan Leihitu yaitu:

1. Sansksi tidak langsung,

Dalam penerapan sanski tidak langsung bagi mereka yang melakukan penyelewenangan terhadap suatu perjanjian perdamaian berupa pelanggaran atau kejahatan, maka sanksi itu dilandaskan pada pandangan hidup yang bersifat kosmis atau religious magis yang hakikatnya berpegang teguh pada prinsip bahwa kehidupan yang seyogyanya adalah kehidupan yang selaras dengn segala iklim keseimbangan alam semesta ini yang terisi kekuatan gaib. Sehingga terjadinya suatu pelanggaran dapat dianggap sebagai sebab pembawa malapetaka (sial) bagi suatu negri 
2. Sanksi Langsung,

Sansksi langsung dilakukan daam hal pandangan hidup masyarakat yang bersifat kongkrit artinya mereka menghendaki adanya kenyataan dan kefaktaan. Sebagai akibatnya setiap pelaksanaan sanksi terhadap pelaku dilakukan secara pelaksanaan sanksi terhadap pelaku dilakukan secara terangterangan dan terbuka di hadapan umum sebagai satu kenyataan yang telah terjadi

Bentuk-bentuk sanksi adat bagi negeri yang melakukan penyelewengan berupa pelanggaran ataupun kejahatan terhadap kesepakatan perjanjian perdamaian di Kecamatan Leihtu adalah sebagai berikut:

a. Terjadinya musibah (sial) bagi neegeri yang tidak mentaati kesepakatan damai tersebut. Seperti meninggalnya warga masyarakat tanpa sebab yang elas dan wabah penyakit akan melanda negeri yang bersangkutan. Sehingga perlu dilakukan upacara-upacara adat tertentu sebagai penebus atas kesalahan yang dilakukan seperti, cuci negeri dan tolak bala

b. Kutukan atau celaan dari seluruh angota masyarakat di Jazirah Leihitu terhadap negeri yang bersangkutan

c. Melakukan pemboikotan terhadap semua kegiatan masyarakat dari negeri yang bersangkutan

d. Menuntut permintaan maaf terhadap masyarakat negeri yang menjadi korban dari suatu konflik

e. Ancaman berupa akan dilakukannya aksi penyerangan besar-besaran terhadap negeri yang tidak mentaati keputusan lembaga oleh seluruh masyarakat di jazirah Leihitu

Dalam proses penyelesaian satu konflik antara negeri adat di Kecamatan Leihitu aparat kepolisian selalu dilibatkan sebagai penegak hukum Negara. Setiaap persoalan yang muncul antar negeri dalam wilayah Kecamatan Leihitu perlu diselesaikan secara arif dan bijaksana dengan mengedepankan ketentuan-ketentuan atau norma-norma hukum yang berlaku.
Dengan demikian, maka sanksi yang diberikan kepada negeri yang melakukan penyelewengan berupa pelanggaran dan kejahatan terhadap kesepakatan latupati tersebut juga ditindak sesuai hukum negara melalui proses peradilan.

\section{Eksistensi Lembaga Latupati Kecamatan Leihitu}

Terbentuknya Lembaga Latupati Kecamatan Leihitu tidak dapat dipisahkan dari munculnya para pendatang di Jazirah Leihitu pada masa kejayaan Islam dari abad ke-14 dengan mendirikan sebuah pemerintahan yang disebut pemerintahan Hitu di bawah pimpinan "Empat Perdana " dalam menjalankan pemerintahannta ke Empat Perdana ini mengangkat seorang perdana sebagai pimpinan ereka yaitu Perdana Jamilu yang bergelar " Nusatapi ". Setelah \pm 1 abad menjalankan roda pemerintahan, Ke-Empat Perdana ini mengangkat anak dari Perdana Nustapi sebagai pemimpin pemerintahan Hitu (Republik Ulihalawang) yaitu Abubakar yang bergelar " Latu Sitanya"

Para era kepemimpinan Latu Sitanya, kerajaan Hitu mengalami kemajuan dengan dibentuknya lembaga-lembaga yang cukup modern. Dalam menjalankan tugasnya, Latu Sitanya dibimbing dan dilindungi oleh keempat perdana Hitu. Dari keturunan KeEmpat Perdana in banyak melahirkan Raja (ирu latu), pati, dan orang kaya di Jazirah Leihitu dan Maluku Tengah pada umumnya.

Perlu diketahui bahwa terbentuknya lembaga latupati ini dilatarbelakangi oleh hubungan kekerabatan yaitu ikatan genealogis yang tersusun menurut garis kebapakan (patriliniar), persamaan bahasa, wilayah toritorial, adat-istiadat dan persamaan kebiasaan.

Sejarah mencatat bahwa lembaga latupati ini telah banyak memberikan kontribusi penting bagi terciptanya stabilitas nasional. Konfrensi latupati wilayah Ambon yang berlangsung di Pendopo Gubernur Mangga Dua Ambon dari tanggal 5-6 Maret 
1958 yang membahas tentang tiga materi pokok, sebagai berikut :

1. Menjawab perkembangan negara dewasa ini ditinjau dari segi pembaharuan masyarakat negeri.

2. Solusi kesulitaan ekonomi yang harus ditmpuh rakyat dan pemerintah

3. Kewaspadaan nasional

Sebagai lembaga hukum adat, kedudukan latupati sangat berarti di mana mereka mempunyai ikatan dalam kesatuan adat. Selanjutnya lembaga ini juga mempunyai andil dalam menciptakan perdamaian di Pulau Ambon pasca konflik kemanusiaan tahun 1999 dengn dihasilkannya kesepakatan Malino pada tanggal 12 Agustus 2002

Dalam menjalankan tugasnya lembaga latupati selalu mengedepankan koordinasi dan infrmasi sesuai dengan rasa tanggung jawab moral mereka terhadap ketertiban dan keamanan di wilayah territorial, serta menunjung tingi nilai-nilai kebersamaan, kekerabatan dan musyawarah untuk mufakat.

Latupati sebagai lembaga hukum adat adalah suatu badan tempat berkumpulnya pemerintah dari negeri-negeri di wilayah kerjanya untuk memusyawarahkan sesuatu yang bertalian dengan adt. Mereka bisa berpendapat mengenai suatu persoalan, misalnya mengenai suatu sengketa antara dua negeri atau mengenai penerapan hukum adat. Lembaga ini tidak bisa memaksakan pendapat ereka itu pada pihak-pihak lain atau negeri-negeri yang bersengketa, sebab badan ini tidak mempunyai kekuasaan aministratif terhadap suatu negeri yang tergabung di dalamnya. Dengan demikian maka pola kerja lembaga latupati dalam menyelesaikan suatu prmasalahan tergantung dari pada bentuk permasalahan itu sendiri

\section{PE N U T U}

Masyarakat hukum adat di Maluku terbentuk berdasarkan faktor wilayah dan keturunan (toritorial daan genealogis) sangat berpengaruh pada pembentukan lembagalembaga hukum adat yang mencerminkan karakteristik dari keberadaan tersebut. Pada saat ini leembaga latupati sebagai salah satu lembaga hukum (institusi adat) di Kecamatan Leihitu yang melambangkan karakteristik orang Maluku yang selalu menunjung tinggi nilai-nilai kebersamaan daan kekerrabatan tanpa memandang latar belakang status sosial dan agama telah mengalami degradasi (pemiskinan fungsional), hal ini dipengaruhi oleh semakin terkikisnya nilai-nilai budaya orang basudara di Maluku.

Perkembangan zaman berdampak pada interaksi antara sesama orang basudara di Maluku yang semakin cenderung kepada individual (egoisme) dan pola-pola hidup yang bertentangan dengan nilai-nilai dan norma hukum adat. Dengan demikian bahwa lembaga latupati Kecamatan Leihitu pun tidak terlepas dari pengaruh tersebut. apa yangdisebut sebagai pemegang peran dalam satu daerah kesatuan hkum adat akan menjadi kurang efektif sehingga eksistensinya perlu dijaga dan lebih ditingkatkan demi mewujudkan ketertiban dan keamanan khususnya di Kecamatan Leihitu dan Provinsi Maluku pada umumnya sesuai dengan amanat dan cit-cita negara kesatuan Republik Indonesia. Dengan demikian disarakan perlu kontekstualisasi fungsi perekat social budaya lembaga latupati secara keseluruhan seiring dengan tantangan masyarakat yang semakin sosialisasi peraturan perundangundangan baik pusat maupun daerah dan sebagai integritas multi kultur yang lebih komprehensif. 


\section{DAFTAR PUSTAKA}

Cohen. J. Bruce, Sosiologi Suatu Pengantar, PT. Rineka Cipta, Jakarta, 1998.

Efendi Ziwar, Hukum Adat Ambon-Lease, PT. Pradnya Paramitha, Jakarta, 1978.

Haar Ter B, Asas-asas dan Susunan Hukum Adat, PT. Pradya Paramitha, Jakarta, 2001.

Halim Ridwan, Hukum Adat Dalam Tanya Jawab, Ghalia Indonesia, Jakarta, 1985.

Hendricks William, Bagaimana Mengolah Konflik, PT. Bumi Aksara, Jakarta, 1996.

J.A. Mastembroek, Penanganan Konflik dan Pertemuan Organisasi, Universitas Indonesia Press, Jakarta, 1986.

J.A. Pattikayhatu, Sejarah Daerah Maluku, Departemen Pendidikan dan Kebudayaan, Ambon, 1993.

J. E. Lokollo, Sari Budaya Pela-Gandong Dari Pulau Ambon, Lembaga Kebudayaan Daerah Maluku, Ambon, 1997.

Koesnoe, Moh, Hukum Adat Sebagai Satu Model Hukum, CV. Modern Maju, Bandung, 1992. 